\title{
A REVIEW OF THE GENUS MALLADA \\ IN THE UNITED STATES AND CANADA, WITH A NEW SPECIES (NEUROPTERA: CHRYSOPIDAE)
}

\author{
By Phillip A. Adams ${ }^{1}$ And J. Allan Garland ${ }^{2}$
}

Analysis of the Canadian chrysopid fauna (Garland, 1981) revealed an undescribed species of Mallada ranging into southern Ontario. Accordingly, a draft description and illustrations were transmitted to the senior author. As few of our species have been given modern redescriptions, it is appropriate to review the status of all four known members of this genus from the U.S. and Canada.

The taxonomic status of Mallada was discussed by Adams 1975, and a detailed treatment of genitalic morphology given by Principi 1977. The genus is characterized by: left mandible toothed, inner gradate crossvein of forewing ending in a branch of radial sector, not on pseudomedia (Fig. 20); pseudomedia not comprising any crossveins; micropoculae or cuticular glands present on male pronotum, microtholi absent, tignum and gonapsis present, arcessus normal; ectoprocts and hypovalva (eighth and ninth sternites) without unusual projections, larva trash-carrying and overwintering (Séméria, 1977).

Mallada is primarily an Old World genus, constituting a major part of the chrysopid fauna of Europe, Africa, India, Southeast Asia, and Australia. Although New 1980 does not subdivide the Australian "Chrysopa" into genera, or species groups, it is possible tentatively to assign species on data given; 15 of the 47 species of Chrysopinae fall into Mallada. Tjeder 1966 points out that 19 of the 39 African "chrysopas" (Saurius + Glenochrysa + Chrysoperla + Brinckochrysa + Apertochrysa + Anisochrysa) are assignable to Anisochrysa (i.e., Mallada), and places 22 additional Old World species in that taxon. Aspöck et al. 1980 list 15 European Mallada species (as Anisochrysa). In the New World, there are only 5 known species, M. (Triadochrysa) triangularis Adams 1978 from Mexico, and the other North American species discussed below.

\footnotetext{
'Department of Biology, California State University, Fullerton, California 92634. ${ }^{2}$ Department of Entomology, Macdonald College of McGill University, Ste-Annede-Bellevue, Quebec H9X 1C0

Manuscript received by the editor August 16, 1982.
} 


\section{Mallada macleodi sp. nov.}

DesCription. Head narrow, pale green, eyes large, antennae unmarked; genae with a shiny narrow black band from margin of eye, extending to anterior lateral edges of clypeus; labrum black posterolaterally, green medially (Fig. 3); palpi blackish throughout; frons raised anteriorly; face with scattered setae, some longer anteriorly on clypeus.

Thorax pale green, pronotum with two anterolateral brown patches; setae whitish. Legs green, pretarsal claws deeply excised.

Abdomen green, setation normal, microtholi absent.

Male terminalia (Fig. 2). Sternites VIII+IX fused, elongate; dorsal apodeme long, prominent; ventral apodeme absent. Genitalia (Fig. 1) with broad transverse tignum; gonarcus expanded laterally, rectangular dorsally; entoprocessus prominent, expanded ventromedially; arcessus broadly continuous with dorsum of gonarcus, sclerotised proximally, produced caudad and slightly down-curved, apex bluntly pointed; gonosaccus rudimentary, with only a few small straight gonosetae positioned between the ventromedial expansions of the entoprocessus; gonapsis (Figs. 9, 10) three-pronged, with lateral wings narrow, the caudal process dorsoventrally expansive proximally and tapering as an acuminate downcurved hook, broad internal saccus terminates in a vertical lobe; gonocristae sparse and only minutely developed on hypovalva.

Female terminalia. Subgenitale membranous proximally, with many microthecae; apical lobe notched; transverse callus prominent, with an ental excavation but not a cavity. Spermatheca (Fig. 4) pillbox-shaped; vela tubular, conspicuously bent toward spermathecal bulb.

Wings. Pterostigmata prominently marked, brownish. Venation narrowly margined with brownish amber, especially in forewing, gradates of forewing dark, of hind wing amber. Many crossveins of forewing dark; costals all dark, male with 19 (22.7) 26, female with

Fig. 1-4, Mallada macleodi: 1, dorsal aspect of male genitalia (Ontario); 2, same, terminalia with structures everted; 3 , labrum and mandibles, female, Ontario; 4 , same as 3, spermatheca. Fig. 5-8. Mallada perfectus: 5, dorsal aspect of genitalia; British Columbia; 6, same as 5, male terminalia with structures everted; 7, labrum and mandibles, female, British Columbia; 8, same as 7, spermatheca. Scale is for genitalia and spermathecae. 


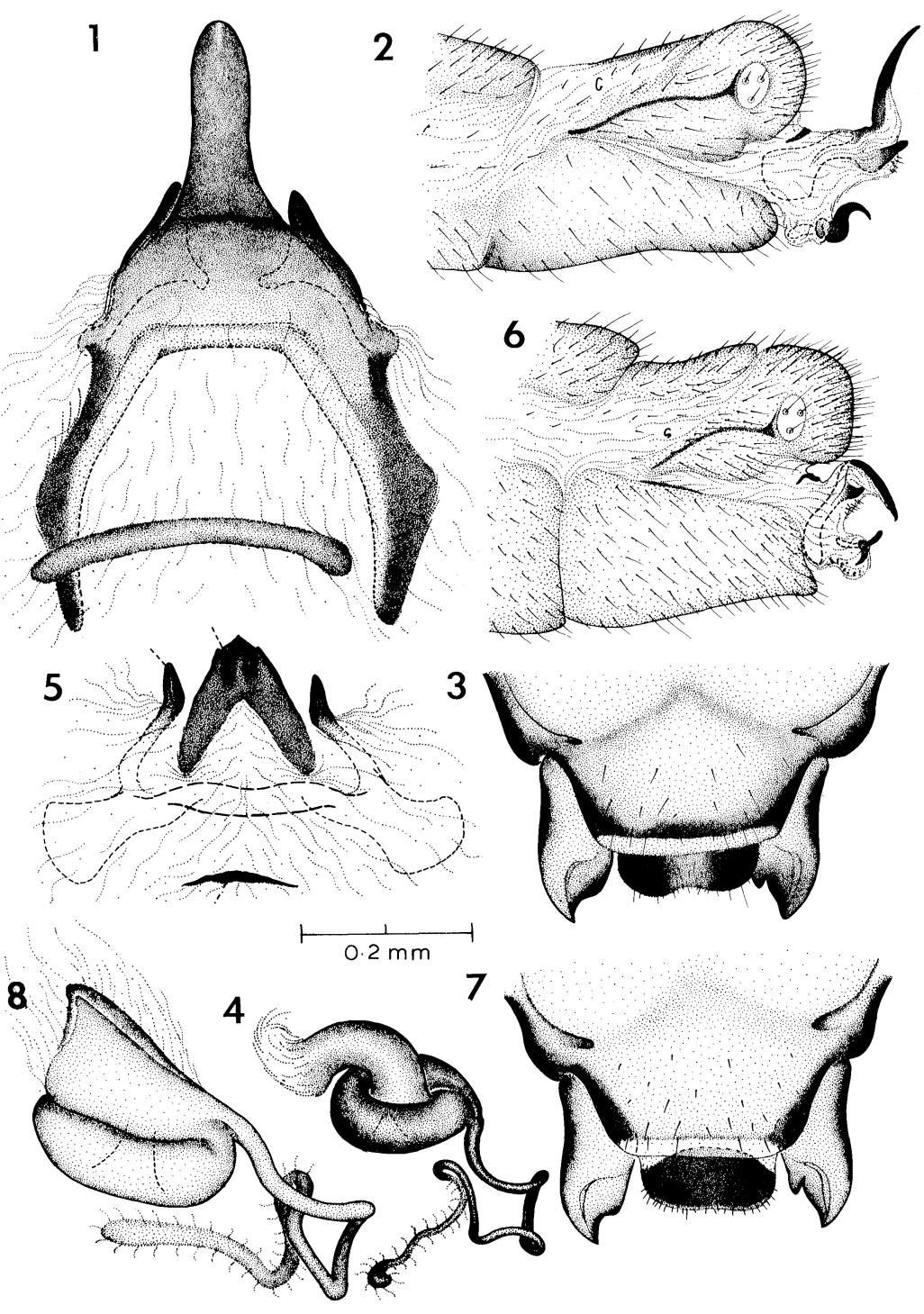


21 (24.2) 26 (mean in parentheses). Inner gradate series of forewing normal for the genus, terminating on a branch of the radial sector (Fig. 20). Forewing length: male 10.0 (11.5) 12.5, $\mathrm{n}=10$; female 12.0 (13.0) $13.7, \mathrm{n}=10$ (mm, mean in parentheses). TYPE MATERIAL. Holotype: TeXas, Erath Co.: Stephenville, 20. iv.1981, $\hat{\not}$, C. W. Agnew (MCZ No. 32576).

Paratypes. ARIzona. Santa Cruz Co.: $2 \mathrm{mi}$ SW Patagonia, 30.VII.1948, F. Werner \& W. Nutting, rich willow-cottonwood bottom, $4050 \mathrm{ft}$. (MCZ). Yavapai Co.: Granite Dells $4 \mathrm{mi}$. N. of Prescott, 28.vii. 1970, 1 ô, L. Martin (LACMNH). KANSAS. Manhattan: VI, 1 ô, R. C. Smith (CNC, det. Smith [as Chrysopa cockerelli]); VI 1 ô; 17.VI.1920, 1 \%; 19.VIII.1920, 1 \%; 9.VII.1921, 1ठ; 8.IX.1921,

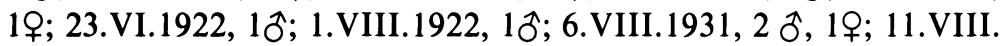
1931, 1 ô, (R. C. Smith, KSU). ontario. Durham Co.: Kendal, 17.VII.1967, 1 \%; 24.VII.1967, 1ㅇ, J.C.D. Riotte \& L. Kohalmi, ultra-violet light (ROM). Lambton Co.: Pinery Prov. Pk., Ausable River near riverside campground, 3.VII.1977, sweeping understory shrubs, 1 Oे, E. Oleksuik (ROM \#770108). Renfrew Co: White Lake, 4.VIII.1966, 1 ㅇ, P. D. Hebert, ultra-violet light (ROM, in fluid).

TEXAs. Chisos Mts., 9-10.VII, 1 ? [abdomen missing], 9-12. VII, 1 $\hat{\delta}$, W. Nutting \& F. Werner (MCZ Paratype No. 32576). Erath Co., Stephenville, 8.v.28.v.1981, 52 specimens, C. W. Agnew (MCZ, PAAC, CWA). Burnett Co.: Inks Lake St. Park, 4.iv.1981, 1 우 C. W. Agnew (CWA). Randall Co.: Palo Duro Canyon St. Park, 11.v.61, 50 specimens, L. Martin, R. H. Reid, W. A. Rees, R. J. Ford (LACMNH). MARYLAND. Howard Co.: 12.vii.1967, 1 ô, 1 q, at white light, E. MacLeod [labelled as "Chrysopa sp. indet., det. E. G. MacLeod] (PAAC).

Remarks. The specific epithet recognized Ellis G. MacLeod, who many years ago collected material of this species, pointed out its existence to the senior author, and generously presented material for study. This species is easily separable from luctuosus and sierra by its lack of black pronotal markings, but is easily confused with perfectus, which differs in having an entirely black labrum, usually fewer and paler costal crossveins, and more prominently brownbordered venation. It is safest to verify identifications by genitalic dissection. 

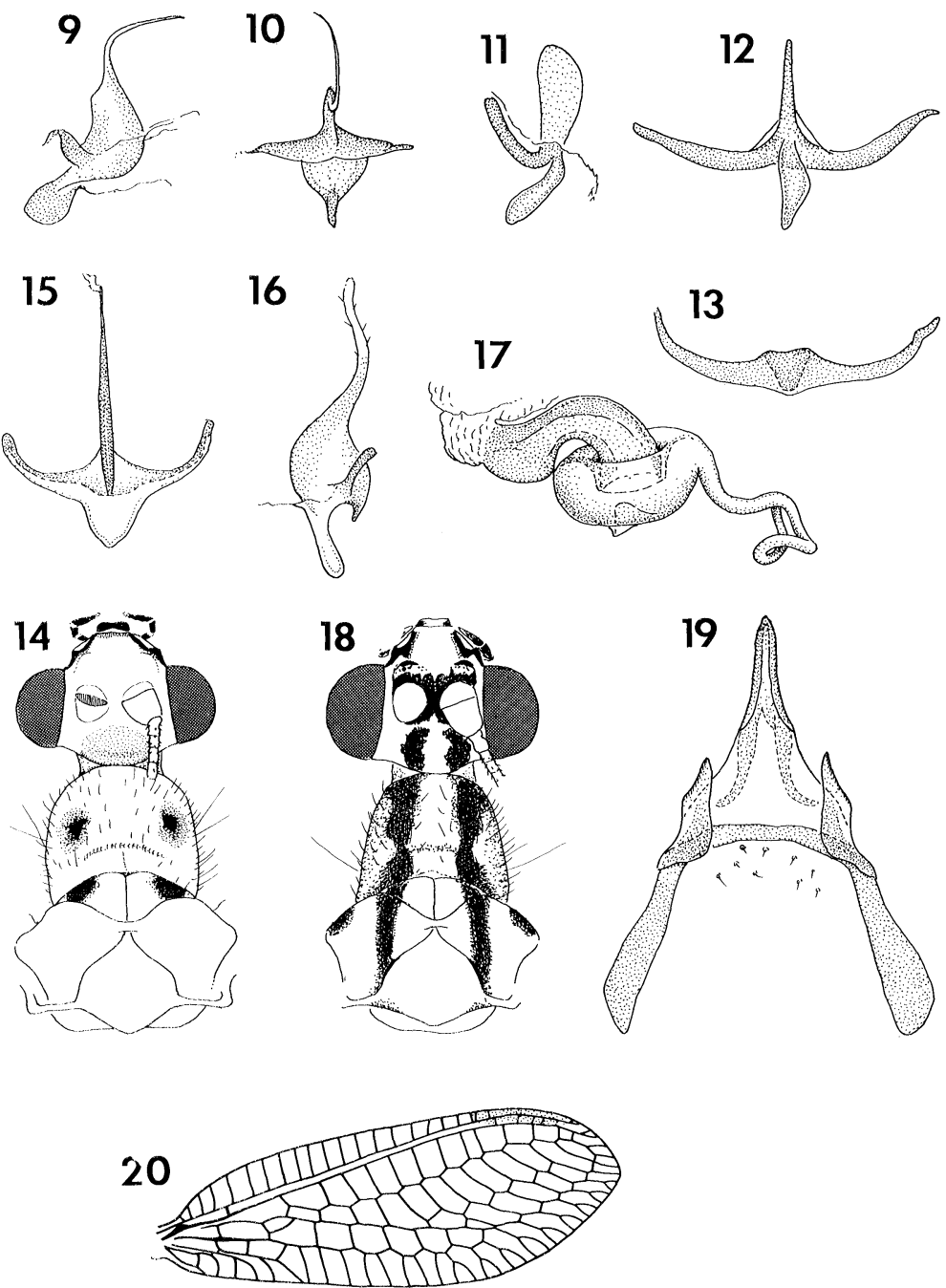

Fig. 9-10. Mallada macleodi: gonapsis, lateral and dorsal views, Texas. Fig. 11-12, M. perfectus: gonapsis, lateral and posteroventral views, Shasta Co., Calif. 13-14, M. sierra: gonapsis dorsal, head and thorax, dorsal; Fig. 15-19, M. luctuosus: 15-16, gonapsis, ventral and lateral views; 17 , spermatheca; 18 , head and thorax, dorsal; 19, gonapsis and arcessus, ventral. Fig. 20, M. macleodi, venation of male forewing, Ontario, showing inner gradate vein ending on a branch of radial sector (and an extra crossvein, in the last gradate cell, a not-uncommon condition). 
The new species clearly was the insect which the late Dr. R. C. Smith studied from Manhattan, Kansas (Smith 1922, as Chrysopa cockerelli). His immatures were debris carriers and overwintered as larvae, confirming the generic assignment. Smith found adults in June (CNC), others in August in association with willows; he deserves credit for observing that the "black lines to mouth not connecting, though the labrum is light brown" (Smith op. cit.: 1367, including Fig. 163). Consequently, we have a fairly complete description of the immature stages of the new species, and it is the only Nearctic representative of Mallada to have been studied in such detail.

On present evidence, the new species occupies the central part of the continent, ranging into Canada in southern Ontario and coming into contact with the more western M. perfectus in Arizona and New Mexico.

\section{Mallada perfectus (Banks 1895)}

Chrysopa perfecta Banks 1895: 516-517. Holotype + MCZ No. 11914, El Taste, Baja Calif.

Chrysopa cockerelli Banks 1903:154-155, new synonymy. Holotype $q$ MCZ No. 11375, East Las Vegas, N. M.

Chrysopa marginalis Banks 1906a:5 (not C. marginalis Navás 1905).

Chrysopa injusta Banks 1906b:98-99, new synonymy. Holotype + MCZ No. 11374, Mts. nr Claremont, Calif. (Baker).

Mallada perfectus (Banks), Adams 1975:172.

DESCRIPTION. Genal stripe black, labrum (Fig. 7) wholly black, palpi black, antennae pale. Body light green with no middorsal stripe, pronotum with two cinnamon-brown patches. Wings with costal veinlets black at ends, pale in middle, $\hat{\sigma}$ costal veinlets: 16-(18.7)-21, $\mathrm{N}=10$; ᄋ: 18-(20.3)-22, $\mathrm{N}=10$ (mean in parentheses); transverse veins conspicuously brown-bordered.

Male terminalia. Apodeme of ninth tergite articulates on short apodeme of sternites 8+9 (Fig. 6), arcessus (Fig. 5) short, broad, with lateral subapical projections; gonapsis (Fig. 11-12) with spatulate emergent process, well-developed arms and simple internal bulb. Gonocristae small, but larger than in M. macleodi.

Female. Spermatheca with broad-based usually short erect vela.

Distribution. Calif., Ore., Wash., British Columbia, Wyoming, Utah, Colo., Ariz., N.M., Baja Calif. 
Remarks. This species occurs throughout the Western United States, but is commonest in the Southwest. The short mediuncus and spatulate process of the gonapsis readily distinguish the males from those of $M$. macleodi, and the females are identifiable by the broad-based erect vela. Some Arizona specimens have the vela nearly as elongate as that of macleodi, but never curved.

\section{Mallada sierra (Banks) new combination}

Chrysopa sierra Banks 1924:431.

DESCRIPTION. This species is structurally and colorationally like $M$. perfectus, except for the following: pronotum with 2 black spots each surrounded by a patch of cinnamon brown (Fig. 14). Mesoprescutum with 2 black spots. Wings with black spot at base of costal area; forewing with black spot at intersection of $2 \mathrm{~A} 2$ and $3 \mathrm{~A}$. Crossveins darker than in perfectus, and brown-bordering of veins less pronounced. Gonapsis (Fig. 13) with chisel-shaped reduced medial process and reduced bulb. Gonocristae less developed than in perfectus.

Material Examined. Holotype 9 , Calif., [Los Angeles Co.], San Gabriel Mts., Sister Elsie Peak, 10-vi [F. Grinnell] MCZ No. 14858. Additional: CALIF., Shasta Co., $10 \mathrm{mi}$. N. Redding, Mountaingate, $1000 \mathrm{ft} ., 4-8 . v i .1981,7$ \%, R. B. Miller (PAAC), 8 mi. N. Redding,

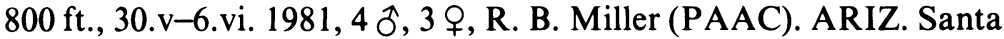
Rita Mts., 24.vii.1927, R. H. Beamer (PAAC ex R. C. Smith). ORE. Jackson Co.: Green Springs, 27.viii.1962, J. S. Buckett, 1 \&. WASH. Yakima Co.: Ft. Simcoe, 1.viii.1962, J.F.G. Clarke, 1 q, (USNM).

REMARKS. This species is readily distinguished by the pronotal and mesonotal markings, and in the male by the simplified structure of the gonapsis. There has been some question as to whether sierra is a distinct species or merely a colorational variety of perfectus. In Shasta County, where these two species are sympatric, sierra appears early in the season, and perfectus somewhat later, pointing to the possibility of some seasonal isolation; in 1981, sierra was relatively common while perfectus was scarce (R. B. Miller, pers. comm.) thus providing some indication of the independence of population fluctuations in these two taxa. The interaction of these two 
species is at present under study by C. A. Tauber (pers. comm.), who reports that they interbreed readily in the laboratory. Despite this, because of the consistence of the colorational and male genitalic differences, plus slightly divergent seasonality, it seems preferable to regard sierra as distinct.

\section{Mallada luctuosus (Banks)}

Chrysopa luctuosa Banks 1911:343.

Mallada luctuosus (Banks) Adams 1975:172.

DesCription. Green, antennae pale, head and thorax marked with black and brown as in Fig. 18; brown stripes continue over metathorax and abdomen. Thorax with longitudinal pleural stripe. Forewings with bases of longitudinal veins, except costa and radius, dark, transverse veins dark; hind wings less prominently darkveined. Abdominal sternites heavily dark-marked.

Genitalia. Arcessus (Fig. 19) elongate. Gonapsis (Fig. 15, 16) with emergent process thin, ribbonlike apically with seta-like projections; anterior pocket wide-based. Spermatheca with tubular arcuate vela inserted in doughnut shaped body, ventral impression small.

Material Examined. Holotype $\hat{\delta}$, N.M., Ft. Wingate, 26.vi, MCZ No. 11383. Additional: ARIzona. Madera Can., Santa Rita Mts., 16.viii. 1949, P. Adams (PAAC); Cochise Co.: Huachuca Mts., Sunnyside, 14.vii.58, L. Martin (PAAC); Chiricahua Mts., S.W. Research Station, 5 mi. W. Portal, 5400 ft., 1.viii.1966, R. E. Dietz (PAAC), 28.vi.1960, J. M. Linsley (U. Calif. Davis); Globe, Pinals, 18.vii.1948, W. Nutting, F. Werner (MCZ). Colorado. Mesa Verde Nat. Park, Campground, 12.vii.1959, J. \& C. Northern (LACMNH). NEBraSKa. Meadville, 10.vi.31, B. Patterson (FMNH, Chicago).

Remarks. This species is immediately recognizeable among $\mathrm{Mal}$ lada species by the dark longitudinal veins and conspicuous black and brown body markings. It is interesting to note that the forms of the arcessus, gonapsis, and spermatheca are more similar to those of macleodi than are those of perfectus, despite the extreme colorational differences. 


\section{ACKNOWLEDGEMENTS}

D. K. McE. Kevan encouraged one of us (J.A.G.) to study the Canadian chrysopid fauna, which led to discovery of the Ontario specimens and preparation of the draft manuscript and species description, including privately financed travel to Ottawa and Boston. Material for study was loaned by H. D. Blocker, Kansas State University (KSU); Mary Hathaway, and K. Jepson, Museum of Comparative Zoology, Harvard University (MCZ); J. E. H. Martin, Biosystematics Research Institute, Agriculture Canada, Ottawa (CNC); C. W. Agnew, Texas Agricultural Experiment Station; G. B. Wiggins and B. D. Marshall, Royal Ontario Museum (ROM), C. L. Hogue, Los Angeles County Museum of Natural History (LACMNH). R. B. Miller collected critical material of M. sierra and perfectus.

\section{REFERENCES}

Adams, P. A.

1975. Status of the genera Ungla and Mallada Navás (Neuroptera: Chrysopidae). Psyche, Camb. 82:167-173.

1978. A new species of Hypochrysa and a new subgenus and species of Mallada (Neuroptera: Chrysopidae). Pan-Pacific Ent. 54:292-296.

AsPöck, H., U. AsPöcK, AND H. Hölzel

1980. Die Neuropteren Europas. Goeke and Evers, Krefeld, 2 vol.

Banks, N.

1895. Some Mexican Neuroptera. Proc. Calif. Acad. Sci. (Ser. 2) 5:515-522.

1896. A new species of Meleoma. Ent. News 7:95-96.

1903. A revision of the Nearctic Chrysopidae. Trans. Am. ent. Soc. 29: 137-162, pl. II.

1906a. Descriptions of new Nearctic Neuropteroid insects. Trans. Am. ent. Soc. 32(1905): 1-20, pl. I, II.

1096b. Three new species of Neuroptera. Psyche Camb. 13:98-100.

1911. Descriptions of new species of North American Neuropteroid insects. Trans. Am. ent. Soc. 37:335-360, p. XI-XIII.

1924. Descriptions of new Neuropteroid insects. Bull. Mus. Comp. Zool. 65:419-455, p. I-IV.

Bickley, W. E., AND E. G. MaCLeod.

1956. A synopsis of the Nearctic Chrysopidae with a key to the genera (Neuroptera). Proc. ent. Soc. Wash. 58:177-202.

Garland, J. A.

1981. The taxonomy of the Chrysopidae of Canada and Alaska (Insecta: Neuroptera). Ph.D. Thesis, McGill University. 
New, T. R.

1980. A revision of the Australian Chrysopidae (Insecta: Neuroptera). Aust. J. Zool. Suppl. 77:1-143.

PRINCIPI, M.

1977. La morfologia addominale ed il sue valore por la discriminazione generica nell'ambito delle Chrysopinae. Boll. Ist. Entomol. Univ. Bologna 31:325-360.

SÉméria, Y.

1977. Discussion de la validite taxonomique du sousgenre Chrysoperla Steinmann (Planipennia, Chrysopidae). Nouv. Rev. Ent. 7:235-238.

SMITH, R. C.

1922. The biology of the Chrysopidae. Cornell University Agric. Exp. Sta. Mem. 58:1287-1372, pl. LV-LVIII.

TJEDER, B.

1966. Neuroptera - Planipennia. The lace-wings of southern Africa. V. Family Chrysopidae. S. Afr. anim. Life 12:228-534. 

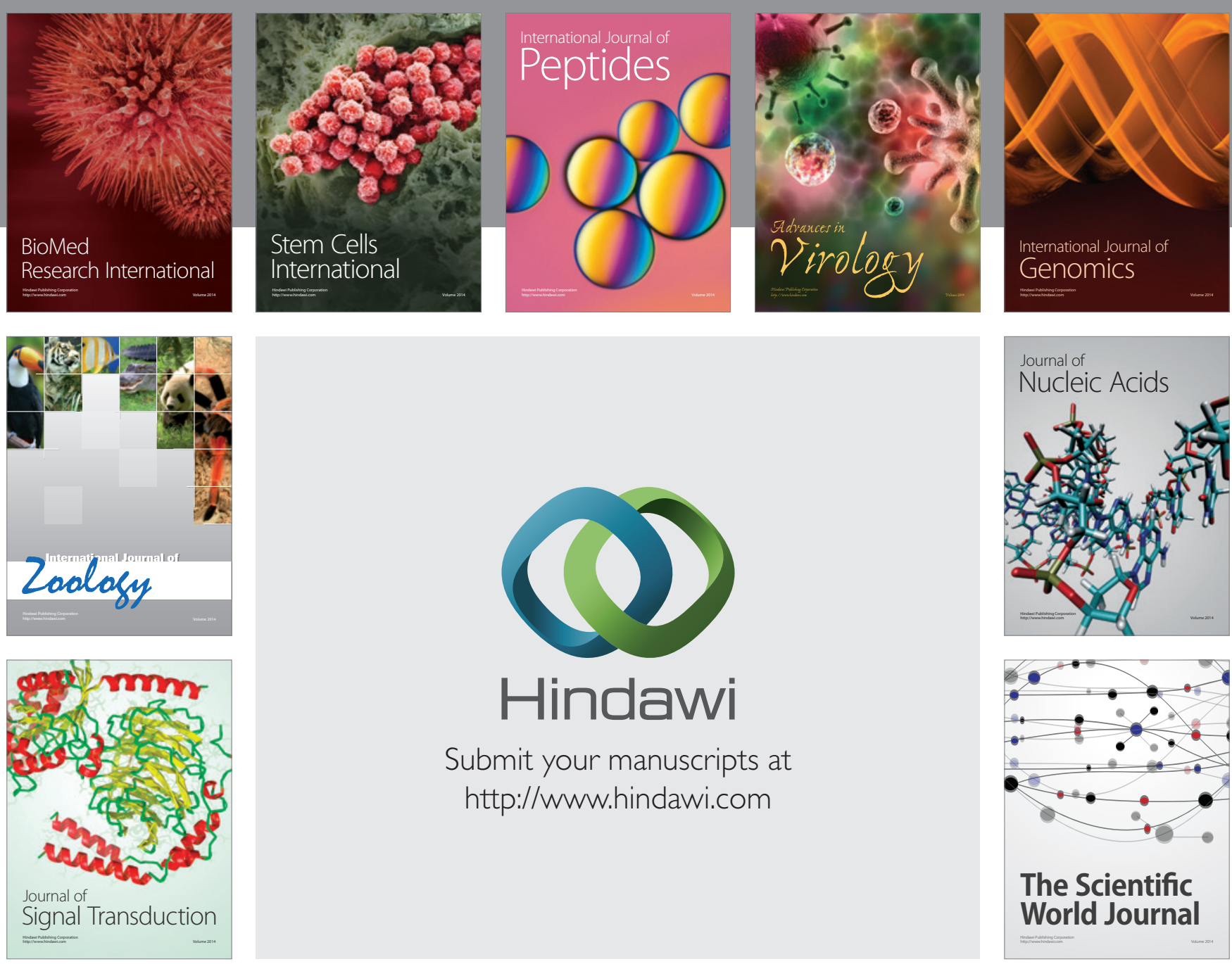

Submit your manuscripts at

http://www.hindawi.com
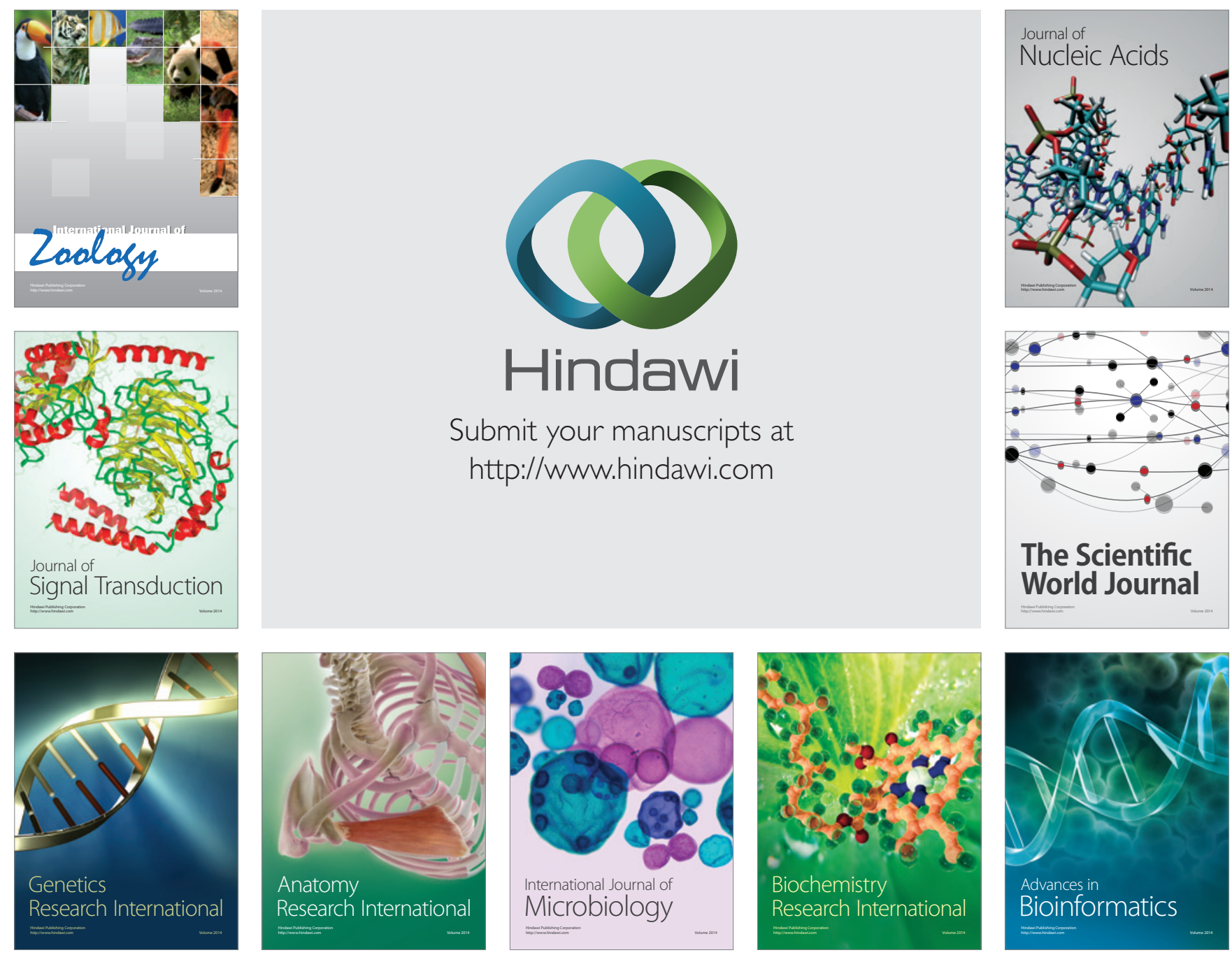

The Scientific World Journal
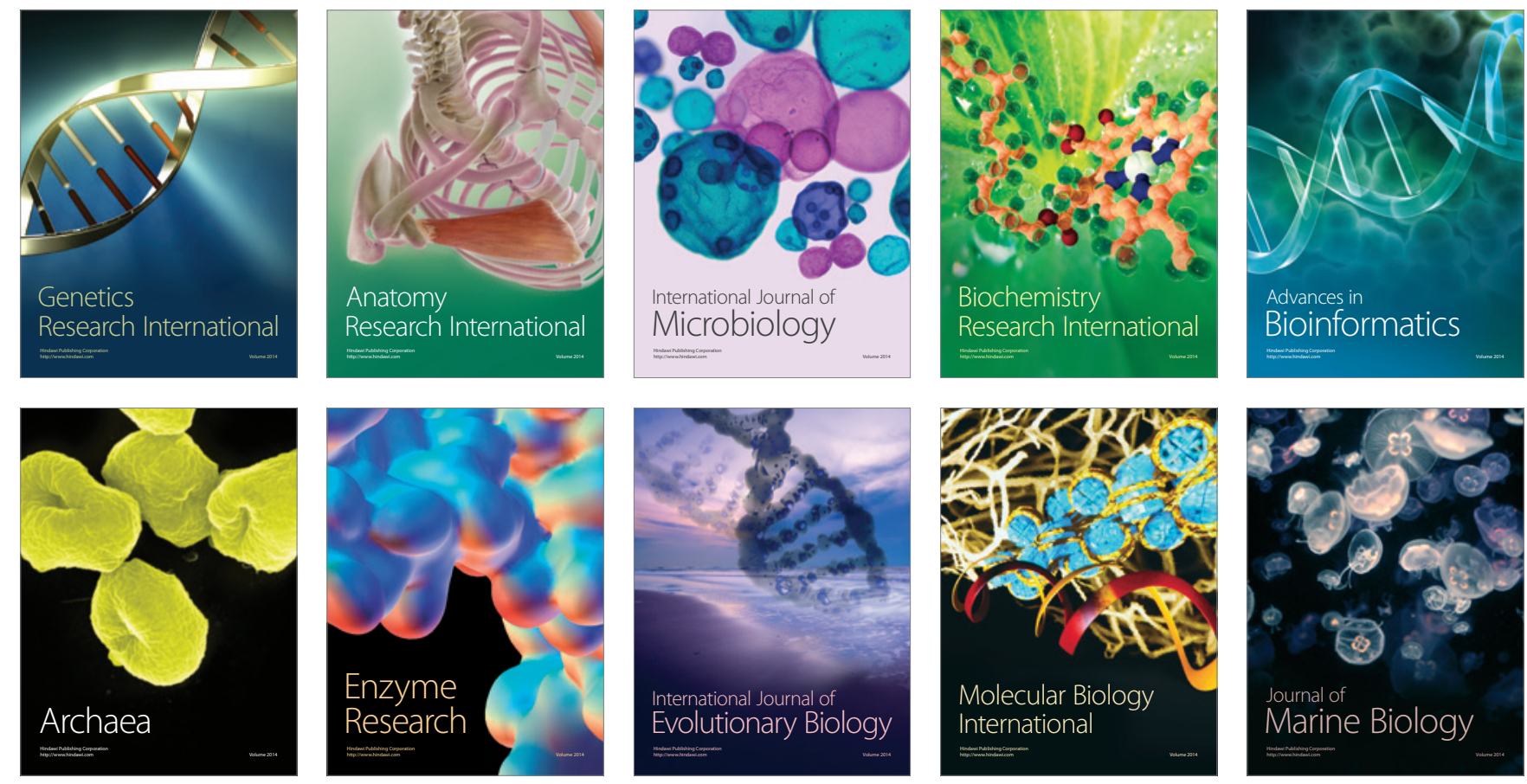